\title{
The Illiterate African Woman as Depicted in Ama Ata Aidoo's Anowa
}

\author{
Priscilla Appiah, \\ Edward Owusu, \\ Asuamah Adade-Yeboah, \\ Alberta Dansoah Nyarko Ansah
}

\begin{abstract}
Based on the theory of existentialism, this study seeks to find out Ama Ata Aidoo's view on how illiteracy affects the African Woman in her drama, Anowa, which was published in 1970. The text depicts the illiterate woman as being powerful woman in African society. However, Ama Ata Aidoo posits that illiteracy makes the woman a pathetic individual who is not able to function effectively in this changing world. This study seeks to deepen the appreciation of Ama Ata Aidoo's Anowa, by contributing to the understanding of Aidoo's attitude to the illiterate Ghanaian woman (and for that matter African woman) who is seen as a powerful matriarch, but frustrated by African society as a result of lack of formal education. The available literature was explored to find what other writers have said on Aidoo's Anowa. We used the method of qualitative content analysis in our analysis. The findings of the study show that Ama Ata Aidoo uses her writing to satirize societal weaknesses for her readers to refrain from committing such wrongs. Her illiterate women characters in Anowa are bent on maintaining their traditions and are not prepared for change. Consequently, Aidoo uses the character, Anowa, to depict change in African societies.
\end{abstract}

\section{Keywords}

Existentialism, Ghanaian Woman, Illiterate African Woman. 



\title{
The Illiterate African Woman as Depicted in Ama Ata Aidoo's Anowa
}

\author{
Priscilla Appiah, \\ Edward Owusu, \\ Asuamah Adade-Yeboah, \\ Alberta Dansoah Nyarko Ansah
}

\section{Introduction}

African faces a lot of challenges. One of those challenges is illiteracy. Therefore, a host of African writers (from various genres) have shown serious concern about the need for formal education of Africans, especially the African woman. Kuenyehia and Dolphyne, writing from social and legal perspectives, project the illiterate woman in a very pathetic state; and therefore, advocate strongly for formal education of the African woman as the means to a fuller life. In Ghana, some writers have shown concern for women's education. One female Ghanaian writer, who has used her works to present the position of illiterate Ghanaian women, is Efua Sutherland. In her famous play, the Marriage of Anansewa (1981), Sutherland portrays the African woman in several ways. Ama Ata Aidoo is another female playwright who has written extensively on the need for formal education of Ghanaian women. Her novels Our Sister Killjoy (1970) and Changes (1999) have lots of issues on the education of women.

This notwithstanding, in many of her works, Ama Ata Aidoo depicts the strength of the illiterate matriarch in several ways. She portrays the illiterate woman as psychologically advanced, self-expressive, intelligent, powerful in the family, and a leader of her society. Because she is able to resolve conflicts between aggrieved people, the illiterate woman is-presented as a strong and wise entity. The illiterate woman, as projected by Aidoo, exhibits a lot of patience and forgiveness. She is seen as a compassionate and fair-minded individual. An epitome of such a woman in Ama Ata Aidoo's The Dilemma of a Ghost (1965) is Esi Kom. Other examples are the illiterate women in No Sweetness Here and The Message in Aidoo's compilation of short stories entitled No Sweetness Here (1970).

Aidoo's Anowa, the text that the study focuses on, principally presents the heroine Anowa, another illiterate woman, as an individual who is not afraid to question 
certain traditions she finds unfavourable to women. Therefore, Anowa is presented as an intelligent and self-expressive individual who stands for change. This makes her different from the rest of the women in her society. These women, therefore, stand against her because of her unique stance on some societal norms. Anowa can stand firm and succeed in choosing her husband. This decision meets the displeasure of Badua, Anowa's mother, and the old woman, since they consider Kofi Ako, as being the wrong type of man for any girl to marry because 'he combs his hair too often and stays too long at the Nteh games.' Aidoo indicates that in this changing world, lack of formal education renders the woman a pathetic individual who is incapable of functioning effectively in society. This is the problem Aidoo highlights. However, Aidoo portrays the illiterate woman as a powerful entity who stands to challenge the status quo. This paper explores how illiteracy affects the woman in the African society as depicted in Aidoo's Anowa.

Therefore, the current paper is intended to contribute to the understanding of Aidoo's attitude to the illiterate Ghanaian woman who is seen as a powerful matriarch. However, this powerful woman is frustrated by the African society owing to her decision to challenge certain values. The current paper, thus, seeks to deepen the appreciation of Ama Ata Aidoo's work, Anowa. Consequently, the paper is guided by the following questions:

- How does the illiterate African woman exhibit her potential in the society?

- How does illiteracy (lack of formal education) affect the progress of the African woman?

\section{Review of Related Literature}

\section{The Plot}

Anowa is Ama Ata Aidoo's second drama. This drama focuses on Anowa, the heroine, who ignores the traditional custom of marrying a man that is endorsed by the family and goes ahead to marry Kofi Ako, the man of her choice. Because the society disapproves of Anowa's marriage to Kofi Ako, the couple is forced to abscond from Yebi, their village, to sojourn elsewhere. However, they could not live happily ever after since they passed away shortly after they eloped.

\section{Theoretical Framework}

The analysis of the text of the current research, Anowa, is guided by the philosophical theory of existentialism which emphasizes human consciousness-raising, potentiality, individual uniqueness, and enjoyment of autonomy within the constraints of societal rules and regulations that have the propensity of leading to the achievement of self-actualization and total societal development (Elias and Merriam).

The most important belief of existentialists is the dignity and worth of the individual. The existentialists believe and recognize the individuality or uniqueness of the individual, as well as his potentiality. It is, therefore, imperative to develop one's 
individuality by nurturing each person's special talents and skills. The potentiality each person has is inexhaustible (Elias and Merriam). After the development of the individual's talents and skills, he could be used to improve the standard of living for himself and the society as a whole.

Existentialists also believe in the freedom and autonomy of the individual (Costello, Girling, Grudin, and Elias and Merriam). In other words, existentialists believe in free will rather than predestination. They state that human beings are not solely or primarily knowers; they also care, desire, manipulate and above all, choose and act. The claim that man exists in this unique sense also means that he is opened to a future which he determines by his choices and actions; he is free. Thus, man has the capacity to make choices that can affect his life in a number of ways. Elias and Merriam put this particular belief thus: “... a person's behaviour is not determined by external forces or internal urges." (118). Behaviour is, therefore, the consequence of human choice which individuals can freely exercise, as Jean Paul Sartre's statement epitomizes it: "the essence of each human person is the freedom to act, to choose, to say 'no' or 'yes'. Thus, a person is what he or she chooses to be. Existentialists view every human being as an open possibility. They equate man to a process, and that he is able to develop and liberate himself of any uncomfortable situation he finds himself. He is the only person aware of his condition and is capable of bringing about change for the better. The challenge of changing his situation lies squarely on him (Freire). This notion of freedom and autonomy does not mean that behaviour is totally random, uncontrolled, and unaffected by heredity or environment. Rather, it means that human beings are capable of making significant personal choices within the constraints imposed by heredity, personal history and environment. Not all these are predetermined. The individual can be proactive rather than reactive and, in so being, exert an influence on his situation. That is, the force of the person who is free to act can bring about modification for the improvement of one's life and humanity as a whole (Elias and Merriam 118-119).

\section{Illiteracy and its Effect on the African Woman}

Quite a number of studies have been done on Ama Ata Aidoo's Anowa. However, not much has been done on how illiteracy affects the African woman in the society. This section of the literature assesses some of the limited studies conducted on Aidoo's Anowa about the effects of illiteracy on the African woman. Literaure on effect of lack of formal education on the part of the African woman has also been examined.

Illiteracy as a social phenomenon has gone through a lot of changes. Therefore, its definition is usually based on the context in which it is used. Thus, illiteracy as a term has been viewed from different perspectives. For example, it has been widely used derogatively for contexts where some entities fail to measure up to the standards or the expectation of the person commenting.

Shafritz et al. define illiteracy as the inability to read and write at a level expected by one's culture (239). In consonance with Shafritz et al. 's definition, Geddes and Grosset refer to illiteracy as not knowing how to read or write (249). Thus, illiterate 
entity finds it strenuous reading, writing and understanding simple structures. So, it is obvious that these definitions are based on literacy skills. Thus, illiteracy is the inability to read or write, or the perceived state of being uneducated or insufficiently educated. Formally, illiteracy was used to describe someone without book knowledge or a liberal education, even though such a person could read in vernacular or handle accounts and correspondence. Again, the word carries a connotation of 'unpolished', ignorant or inferior individual, as in the disadvantage of an 'illiterate education' (Gibbon 75).

In recent years, the term has been used to describe the condition of people unable to cope with printed materials relevant to their needs and people unacquainted with the canon and conventions of an educated populace. The precise description and accurate estimates of illiteracy of any kind in English-speaking countries are difficult to obtain. Crystal has asserted that, in the developed countries, it is becoming more rather than less difficult for people to achieve an acceptable standard of literacy:

\section{[...] people who had achieved a basic literacy are thus in real danger of being classed as illiterate as they fail to cope with the modern everyday demands of such areas as the media, business, bureaucracy and the law[...](24).}

Based on the analysis of the literature, we can conclude that inability to read and write not only hinders people from operating fully within their communities, but also influences their setting of national priorities and the use of human and material resources. Behrent goes on to say that:
"Aidoo uses the structure, language, and themes of her oral literary heritage but she adapts them to a contemporary subject. This demonstrates the way in which oral literature can be adapted to reflect contemporary issues and in a sense subvert some elements of the oral heritage, as Aidoo does in this play, rewriting history through the legend of Anowa." (64)

Aidoo thus shows the artistic merits of the oral literary heritage and by adapting it to deal with both contemporary and historical issues, and demonstrating that it is not a static art of the past, but rather a living art form which still has artistic and social value. At the end of the play, Anowa, is seen as a haggard, half-mad, dirty and ready-to-be discarded entity. Thus, in many ways one could present her as a symbol of both slavery and Africa. Thus, after Kofi Ako's death, Anowa becomes faded in more ways. Subsequently, her appearance was a symbol of bondage. The feminist stance of the play 
is revealed in this storyline as we watch Anowa move through life from a young carefree girl to a meticulous wife.

In many ways, Odamtten observes that Anowa echoes and modifies the popular folk tale of the disobedient daughter. He goes on to state that critical reactions to Anowa have focused attention on certain aspects of the content of the drama without taking a fuller account of formal characteristics of the play, its wide historical significance, and its relationship to Aidoo's first drama. Brown (95) also states that Anowa, the character, is morally superior woman who valiantly resists the abuse and misuse of power by men and some women in the society that support and encourage sexist exploitation and oppression. Brown (98) argues that Anowa's struggling is the measure of individualism and freedom. According to Odamtten, Brown seems to be unaware of the ideological assumptions implicit in Brown's own assessment of the central issues of Aidoo's play. Odamtten argues about a western imperialist celebration of what only seems to be subjective individualism in its most positive aspect of validating individual choice, as opposed to what is seen as traditional African values that deny the possible choice.

\section{Method}

Qualitative Content analysis design was used for this study. According to Krippendorff, qualitative content analysis design is a research tool used to determine the existence of certain words, themes or concepts within some given qualitative data. Content analysis does not require the collection of data from people (Owusu et al. 2). This kind of analysis plays an integral role in the development of artificial intelligence. It also identifies the intentions, focus or communication trends of an individual, group or an institution. Specifically, conceptual analysis, which is a type of content analysis, was used. Conceptual analysis aims at exploring the occurrence of selected terms in the data. So, the effect of illiteracy as portrayed by the author, Aidoo, was explicitly looked at.

\section{Discussion}

Based on the research questions of the paper, the discussion has been segmented into two subheadings:

\section{How does the illiterate African woman exhibit her potential in the society?}

In the text, the illiterate African woman exhibits strength. In several ways, Ama Ata Aidoo presents significant roles that the illiterate woman plays in the traditional African society. The protagonist, Anowa is portrayed as the only woman who is not afraid to question certain traditional practices she finds unfavourable to women in her society. Anowa's actions in the play portray her as a revolutionary and intellectual woman whose intellect has developed beyond the natural limits of her native intelligence. This situation projects her as being different from her people. Her strong character traits empower her to go beyond the narrow-minded limitations that exist in her world. Anowa does not seem disturbed by the fact that she is a single woman who is in 
the sixth year of her puberty. In addition to this, Anowa is determined to marry a man of her choice and not any man her parents approve of. We see this in her statement to her parents:

\author{
Mother, Father, I have met a man \\ I want to marry... \\ I say I have found a man I would like to marry... \\ Kofi Ako asked me to marry him \\ And I said I will too (14)
}

This attitude of Anowa has never occurred in her community. She seems to not be conforming to tradition. This depicts her assertive and non-traditional character. Though she is an illiterate, she knows what she wants as a woman. Her behaviour is in consonance with Chukwudi's (1978) observation:

[...] the inner rhythm of the non-conforming character paces along outer forces to move at its own rate... if the inner rhythm is stronger, the character eventually triumphs and becomes a hero having the image of what Hegel would call a world historical figure able to live his mark on history (13).

In spite of her illiteracy, Anowa decides to think outside the box. She is a woman who is able to withstand the forces that work against her vision (of society that allows individual choice in marriage, and condemns the interference of the supernatural in human activities), and advocates hard work and is a result-oriented character. This role portrays her as a modern woman who decides things for herself and makes life the way she wants it. Here, Anowa can be likened to Debbie in Buchi Emecheta's Destination Biafra (1982), who expresses her feeling. According to Debbie:

If her parents thought they could advertise her like a fatted cow, they had another thing coming. She would never agree to a marriage like theirs, in which the two partners were never equal ... she did not wish to ... the most expensive cars in the world, be attended by servants . . . she wanted to do more than child breeding and rearing (45).

Similarly, Efua Sutherland uses the heroine, Anansewa in her play, The Marriage of Anansewa (1981), to criticize the cankerous tradition where the woman does not have a hand in the selection of a husband. When her father, Ananse, tries to choose a husband for her (Anansewa), she protests vehemently in these words:

I will not let you sell me like some parcel to a customer,

I will select my lover myself; 
I'll never comply, ...

Never!

Never! (11-12)

The behaviour of Anowa makes her different from the rest of the women. Her weird stance about marriage and other societal issues, therefore, receives opposition and criticisms from the society. Nevertheless, Anowa is bold in executing unusual process. She overcomes pressures from the value systems of the society by choosing her husband herself. Thus, she challenges all forms of imposition in seeking self-fulfillment through procreation. When her mother warns her that "[...] marriage is like a piece of cloth [...] its beauty passes away with wear and tear" (16), Anowa responds:

I like mine and it's none of your business...

I do not care, Mother. Have I not told you that

this is to be my marriage and not yours?...

He is mine and I like him (16).

Existentialists believe in the freedom and autonomy of the individual (Grudin, Elias and Merriam). In other words, existentialists believe in freewill rather than predestination. They state that human beings are not solely or primarily knowers, they also care, desire, manipulate and above all, choose and act. Elias and Merriam (118) believe that "a person's behaviour is not determined by external forces or internal urges." Anowa is not afraid to go out to the unknown town to make a new life for herself. She is very confident of her ability to make her marriage work with or without society's consent. When her mother predicts that she and Kofi Ako (Anowa's husband) will come back to Yebi (Anowa's hometown) in rags, Anowa sees it as a challenge to which she confidently responds:

"You do not have to wait because

we shall not be coming back here to Yebi.

Not for a long time, mother, not for a long, long time" (17).

In the play, Anowa is the only female character who is not at all impressed by wealth. In fact, she refuses to change her lifestyle to suit her husband's affluence. Anowa refuses to walk around in her finery majestically. She refuses to employ the services of househelps [slaves] in doing house chores. As an alternative, she does house chores alone. Again, she cherishes working for a living and also believes that a married couple should complement each other instead of one serving the other. This, also, makes Anowa different from the ordinary African woman. All these character traits found in the heroine, Anowa, set the stage for the numerous conflicts between her and the Yebi society. She is really determined to maintain her stance and thereby change the conservatism of the people. 
Anowa is strong-willed. This is seen in her decision of not going back to Yebi, her hometown. She does not regret her decision to marry a man of her choice. Again, she is very purposeful and has a lot of determination. Aidoo, therefore, uses this illiterate character as a change agent in the Yebi society. This is evident in how Anowa sympathizes with Kofi Ako when she realizes that he is impotent, and her decision to cope with his disability. She is not prepared to retreat to Yebi for the people to humiliate and brand her as stubborn. Anowa supports her stance of not going back to Yebi and her sympathy for her husband with this reaction to her husband:

I cannot my husband. Because I have nowhere to go. I swore

I would not go back to Yebi and I can still live here, can I not?

I would not disturb you. I can stay in my part of the house. Just

don't send me away, we have not seen each other's bed for far too long for it to matter if we don't any more. . . (57).

Though Anowa dies eventually, she may be said to have triumphed because she stands by her word of not going back to Yebi. Apart from her strong will, Anowa's resilient character facilitates her idea of keeping the knowledge of her husband's impotence secret. This information is not exposed to the public domain till Kofi Ako decides to send her away. Anowa's triumph can also be seen in terms of the fact that she works tirelessly to help uplift her husband from the doldrums of poverty. She is also able to break the tradition where women are not allowed to speak their minds by resisting Kofi Ako's pronouncement of sending her away without offering any tangible reason. Costello, Girling, Grudin, and Elias and Merriam support the advantaged position of the illiterate woman when they make the assertion that human beings are not solely or primarily knowers, they care, desire, manipulate and above all, choose and act. The existentialists' claim that man exists in this unique sense, also, means that man is opened to a future which he determines by his choices and actions; he is free. Man makes himself what he is by his choices of way of life (Farrah et al. 754 and Nketiah-Kyeremeh 19). Aidoo succeeds in depicting the illiterate woman in the African society in a very favourable light - a local woman with the personality of an urban-trained person.

Anowa's death is tragic because although the Yebi society sees her as a rebel who goes against the societal norm by choosing her own husband, she takes such a bold decision because it is an affront to her freedom of expression and choice. Ama Ata Aidoo does this to portray to her readers some of the unfavourable African practices, such as getting married immediately after puberty, and not allowing women to choose their own husbands.

\section{The challenges of lack of formal education on the African woman}

Aidoo uses her play to educate her readers about the positive qualities that the illiterate rural traditional woman has. However, a critical look at her work reveals that illiteracy has negative impact on the female characters in the play. Thus, there are 
instances in the play where the illiterate woman is portrayed in an unfavourable manner. Badua, Anowa's mother, and Nana are basically bent on the maintenance of the existing traditional culture to the negligence of change, which Anowa, the protagonist, epitomizes. Badua and the old woman will not allow Anowa to marry Kofi Ako. They think that Anowa has erred by making her own choice of a husband. They refuse to consider the issue of love in this matter. Badua and the old woman, thus, brand Kofi Ako as a lazy 'good-for-nothing-cassava-man' and 'watery male of all watery males' (15).

If these women were formally educated, they would know that love is a strong factor in most marriages, and that Anowa has the right to marry the man she loves. As their tradition demands, these women prefer imposing men on their daughters for marriage. However, there might be other situations where parents give their daughters out for marriage without any reservation on grounds of tradition.

In a number of ways, Badua and the old woman are not progressive. Badua is quite interested in carrying on the traditional role of women. In her opinion, the main expectation of a 'human woman' is for her to:

\author{
marry a man \\ tend a farm \\ and be happy to see her \\ pepper and onions grow. (12).
}

The last line of the extract (12) is a metaphorical statement which means 'give birth to children and be happy to cultivate them.' Although Badua, Anowa's mother, sees procreation as the basis of marriage in their Yebi community, elsewhere in Ghana and Africa, some people marry for other reasons - companionship, security, communication, and improvement in life.

The old woman condemns Anowa's mother, Badua, for supposedly encouraging Anowa to marry rather than becoming a priestess. The old woman believes that the divinities will punish Badua for Anowa's nonconformity to the traditional norms of Yebi. The old woman claims "The gods will surely punish Abena Badua for refusing to let her born priestess dance" (8).

For Aidoo, Anowa's intransigence is not empty defiance but the expression of her desire for change. Anowa's position is clearly supported by the old man who seems to understand that the world is changing and that the people in it must change, accordingly. He sums up Anowa's behaviour: "Anowa is not a girl to meet every day . . . a child of several incarnations; she listens to her own tales, laughs at her own jokes and follows her own advice" (7). The stance that Anowa takes and chooses her own husband without the approval of the whole Yebi society and their subsequent migration to Oguaa is significant. Anowa exhibits assertiveness by exercising her freewill. This act has the propensity of changing the Yebi society, which is still wallowing in conservatism. Her behaviour sets precedence for dynamism in the community, and this is one of the basic tenets that existentialism stipulates (Grudin, Elias and Merriam, 118). 
Ignorance is another handicap or negative effect which the illiterate African woman suffers. In several ways, Aidoo portrays how ignorance has made the illiterate traditional women static to the extent that they refuse to embrace change in their lives. Some of the women are presented as not being analytical enough. This is exhibited in how they become excessively emotional on trivial issues. For instance, Aidoo presents Badua as excessively bothered by her daugther's determination to marry a man that the whole society scorns. Badua easily resorts to self-pity as a means of getting things done her way. This is evident in the mood she exhibits after the heated argument with Anowa over the latter's choice of a husband. She weeps in a pitiful manner and makes emotional pronouncements: "I am in disgrace so suck your teeth at me. Other women certainly have happier tales to tell about motherhood. I think I am just an unlucky woman" (17).

\section{Conclusion}

In conclusion, we argue that basically, Ama Ata Aidoo uses her writing to satirize societal weaknesses for her readers to refrain from committing such flaws. Her illiterate women characters in Anowa (excluding Anowa) are bent on maintaining their traditions and are not prepared to look at issues from a broader perspective. This flaw has the propensity of impeding transformation at every level. Such a flat character trait usually leads entities to their downfall. Anowa's disregard for the traditional system of selecting a husband for a marriageable woman, forces her to migrate to Oguaa with Kofi Ako, where misfortune befalls them and they meet their tragic death. The Yebi society perceives this tragic death as a punishment for rebelling against the norms of the society. However, Anowa's decision of choosing her own husband epitomizes freedom of expression and choice. Every decision has its own consequence. Her action and tragic death symbolize the end of vulnerability, ignorance, and superstition. Her tragic death stands for the end of a dark period - a period which lacks confidence, assertiveness, and analytical thinking.

\section{Works Cited}

Aidoo, Ama Ata. Anowa. Longman Drumbeat Group Ltd, 1970. No Sweetness Here. Longman, 1970.

------. The Dilemma of a Ghost. Longman Drumbeat Group Ltd, 1965.

------. Our Sister Killjoy or Reflection From a Black-eyed Squint. Longman Group Ltd, 1977.

-----. Changes. Sub-Sahara Publishers Ltd, 1999.

Behrent, Megan. Ama Ata Aidoo's Anowa. Honours Thesis, Brown University, 1997.

Brown, Wellesley L. Women Writers in Black Africa. Westport, Conn. Greenwood, 1981.

Costello, Edward B. "Humanism," The American People's Encyclopedia, A Modern Reference Work. Golier Inc., 1966, p. 52-53. 
Crystal, David. Literacy 2000: English Today, Cambridge University Press, 1986

Dolphyne, Florence. A. The Emancipation of Women - An African Perspective. Ghana Universities Press, 1991.

Elias, John L. and Merriam, Sharan B. Philosophical Foundations of Adult Education. Krieger Publishing Company, 1995.

Emechita, Buchi. Destination Biafra. Fontana, 1983.

Farah, Martha Karls, A.B and Kortepeter, Carl Max. The Human Experience - A World History. Merrill, 1985

Friere, Paulo. Education for Critical Consciousness. Shead and Ward, 1974

Geddes \& Grosset. Webster's International Dictionary and Thesaurus. Books are Fun by Reader's Digest, 2010

Gibbon, Edward. The Decline and Fall of the Roman Empire. 1981, Vol 02 p. 175

Girling, D.A. (ed.). Existentialism. Everyman's encyclopedia. New York: E. P. 1978, Vol. 5, p. 22.

Grudin, Robert. Humanism. The new encyclopaedia Britannica. Experience from Developing Countries, Oxford University Press. 1994, Vol. 20, pp. 665-666.

Krippendorff, Klaus. Content Analysis: An Introduction to Its Methodology, 2nd Edition, DOI: 10.4236/oalib.1105677 8 Open Access Library Journal, Edition, Sage, Thousand Oaks, CA, 2004

Kuenyehia, Akua. (2001). Legal Literacy and the process of empowerment. In F.

Dolphyne and E. Ofei-Aboagye (Eds.), Experiences in capacity-building for Ghanaian women (pp. 9-13).Africabib.org.

Chukwudi, Maduka, T. Intellectuals and the drama of social change: the writer's insight. Journal of the Humanities, 1978, pp. 40-58

Nketiah-Kyeremeh, Stephen. (2002). The Contribution of GHACOE Women's Ministry to the Empowerment of Ghanaian Women. A Case Study of the Ministry's Activities in Kumasi Metropolitan Area (Unpublished MA Thesis) A Thesis Submitted to the Institute of Adult Education, University of Ghana, Legon. Unpublished.

Odamtten, Vincent. O. The Art of Ama Ata Aidoo : Polylectics and Reading Against Neocolonialism. Gaineville : University Press of Florida, 2004

Owusu, Edward, Adade-Yeboah, Asuamah, and Appiah, Priscilla. Perceptions of some Africans about post-colonialism as depicted in Jomo Kenyatta's "The Gentlemen of the Jungle”.'Open Access Library Journal, vol. 6, no. 9, 2019, pp.1-8. https://doi.org/10.4236/oalib.1105677

Shafritz, Jay. M.; Koeppe, Richard. P. and Soper, Elizabeth. The Facts on File Dictionary of Education. Facts on File, 1988

Sutherland, Efua. The Marriage of Anansewa. Sedco Publishing Ltd, 1981 


\section{The Authors}

\section{Priscilla Appiah}

Department of Communication Studies, Sunyani Technical University, Sunyani, Ghana

Email: priskokoaa@gmail.com

\section{Edward Owusu (PhD)}

Corresponding Author

Department of Communication Studies, and Directorate of Quality Assurance and Academic Planning, Sunyani Technical University, Sunyani, Ghana

Email: edwardowusu@minister.com

\section{Asuamah Adade-Yeboah}

Department of Communication Studies, Christian Service University College,

Kumasi, Ghana

Email: tonyaay58@gmail.com

\section{Alberta Dansoah Nyarko Ansah}

Department of Languages and General Studies, University of Energy and Natural Resources, Sunyani, Ghana

Email: alberta.nyarkoansah@uenr.edu.gh

\section{The Article}

Date sent: 05/06/2021

Date revised: 14/07/2021

Date Accepted: 15/07/2021 